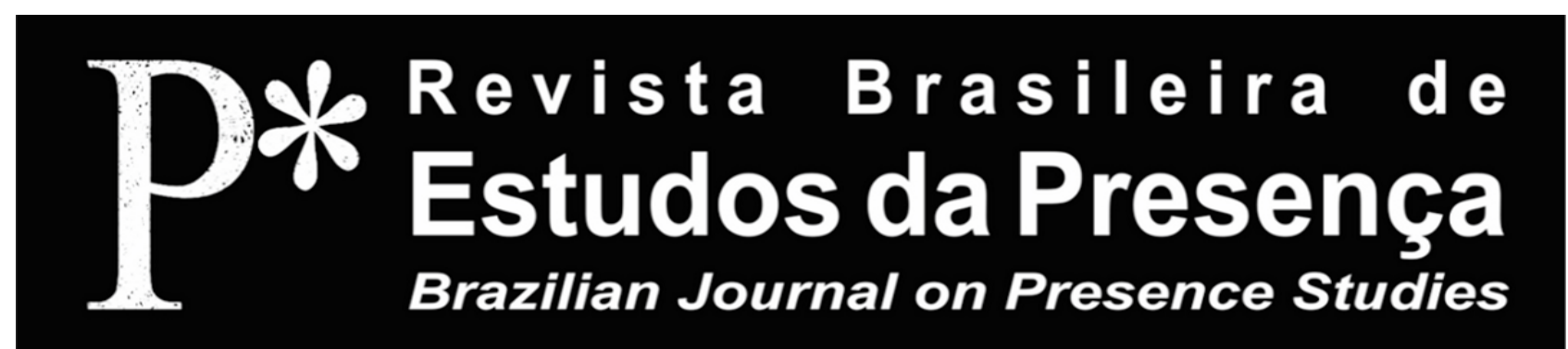

PERFORMING ARTS IN THE SCHOOLS

E-ISSN 2237-2660

\title{
Igbo Language and Literature in Classroom Discourse: a pedagogical experiment
}

\author{
Gloria Chimeziem Ernest-Samuel' \\ 'Imo State University - Owerri/Imo State, Nigeria
}

ABSTRACT - Igbo Language and Literature in Classroom Discourse: a pedagogical experiment - This paper shares a pedagogical experiment of Igbo language instruction using a folktale literature and its film adaptation. The ethnographic study reveals that film viewership affects the students' appreciation of the literature and the language and enhances students' cooperation in sharing and contributing in the learning exercise. The study emphasizes the importance of interactive teaching methods and argues that with globalization and persistent technological invasion, African and cultural studies' scholars need to reflect on innovative approaches to the instruction of local languages and literature to sustain youth interest in African culture/cultural studies in a technological era.

Keywords: Video Film. Literature. Language. Igbo Culture. Pedagogy.

RÉSUMÉ - Langue et Littérature Igbo dans le Discours en Classe: une expérience pédagogique - Cet article présente une expérience pédagogique d'enseignement de la langue Igbo à partir de l'étude d'une légende littéraire et de son adaptation cinématographique. L'étude ethnographique révèle que le visionnage du film a un impact sur l'appréciation de la littérature et de la langue par les élèves et accroît leur coopération, contribuant à l'apprentissage. L'étude souligne l'importance des méthodes d'enseignement interactives et soutient que, en raison de la mondialisation et de l'invasion technologique persistante, les spécialistes des études culturelles et africaines doivent réfléchir à des approches novatrices dans l'enseignement des langues et des littératures locales afin de préserver l'intérêt des jeunes pour la culture et pour les études culturelles africaines à l'ère technologique.

Mots-clés: Vidéo. Littérature. Langue. Culture Igbo. Pédagogie.

RESUMO - Língua e Literatura Igbo no Discurso em Sala de Aula: um experimento pedagógico - Este artigo compartilha um experimento pedagógico de ensino da língua Igbo utilizando uma lenda da literatura e sua adaptação cinematográfica. $\mathrm{O}$ estudo etnográfico revela que assistir ao filme tem impacto na valorizaçáo da literatura e da língua pelos estudantes e aumenta sua cooperação ao compartilhar e contribuir com o exercício de aprendizagem. O estudo enfatiza a importância dos métodos interativos de ensino e defende que, devido à globalização e à persistente invasáo tecnológica, os estudiosos de estudos culturais e africanos precisam refletir sobre abordagens inovadoras no ensino de línguas e literaturas locais para manter o interesse da juventude pela cultura/estudos culturais africanos em uma era tecnológica.

Palavras-chave: Vídeo. Literatura. Língua. Cultura Igbo. Pedagogia. 


\section{Introduction: background to the study}

In 2012, UNESCO listed the Igbo language as capable becoming extinct in 50 years' time. With such a report, the Igbo people of Nigeria faced criticism due to their seeming indifference to the study of Igbo language and literature. The Igbos are believed to be the most westernized of Nigerians; many of them do not read Igbo literature or write and speak the Igbo language proficiently (Asonye, 2013). Many young Igbos are fluent in English, which is the official lingua franca in Nigeria, whereas they hardly read, write or speak Igbo. In Nigerian schools, although Igbo language studies feature prominently in the curriculum, students seem to show no pride in speaking Igbo in public or enthusiasm in reading Igbo literature, regardless of the Igbo people's rich written and oral literary traditions (Ubioworo; Onoyovwi, 2008). These categories are reflected in Igbo studies although Igbo students' approaches to the studies have never been remarkable. Asonye observes that many elite families at home and in the diaspora prefer their children master English rather than Igbo. Owing to this development, many private schools do not employ Igbo teachers in their schools, further resulting in a scarcity of Igbo teachers and interested students. Arguably, students study Igbo language and literature in schools to pass examinations, not due to personal interest. Many cultural enthusiasts and scholars worry that neglect of Igbo language and literature will have negative implications for the people, especially given that Igbo cultural norms and values are transmitted from generation to generation (Odinye; Odinye, 2010). These issues show the need for increased effort in the teaching and appreciation of Igbo language and literature at all levels of tertiary education, and calls for a pedagogical approach to teaching local languages and literature.

Nigerian school children's apparent attitude to learning local languages such as Igbo inspired this study. I argue that adopting contemporary approaches to teaching Igbo language could motivate and arouse students' desire to learn Igbo language and literature as well as Igbo culture. Willam (2013) in his article on Five Principles of Pedagogy ${ }^{1}$ observes that a pedagogical approach must cause (a) motivation (b) exposition (c) 
direction of activity (d) criticism, and (e) inviting imitation. This experiment meets these principles in practice.

\section{Location of the Study}

This ethnographic study and experiment was carried out in Ugwu Orji in Owerri, Imo State. Imo state is one of the core Southeastern states in Nigeria, and the capital of the state thus it is predominantly an urban city. The study was carried out in a private school with senior secondary students. It is practically difficult to get technologically well-equipped schools in rural communities, perhaps owing possibly to lack of patronage. This informs the selection of a private school in an urban location.

\section{Significance of the Study}

Despite the popularity of the Igbo ethnic group and culture, and with growing studies in Igbo language, literature and culture, very few studies have been conducted on Igbo language instruction. Iloene et al. (2013) and Mbah et al. (2013) have examined the use of new technologies for the teaching of Igbo language in schools. However, these studies concentrated mainly on the instruction of Igbo language using media technologies such as podcasts, without any interest in Igbo literature. Mbah et al. (2013) focused specifically on students' experiences and expectations on the use of podcasts for learning English pronunciation. In a related study, Amaechi (2013) applies a phenomenological method in the study of Igbo language involving 561 students from three Junior Secondary schools in Southeastern Nigeria;. The study reveals that the students "[...] prefer a dual-language instruction (DLI) of English and Igbo, which they consider the most effective instructional design to access content. Mother Tongue, they claim, embodies their ethnic identity and helps them decode complex English concepts" (Amaechi, 2013, p. 537). These studies differ extensively from this current study in terms of focus, design and specificity. Therefore, this study is significant because of the specificity of focus on Igbo language in secondary education and its incorporation of literature. Moreover, its small sample size (18 students in a class) is significant because it allow close study of the research participants. The study will thus contribute to closing a gap in the literature. 


\section{Statement of Problem}

As a scholar and culture enthusiast interested in ensuring that the younger generations learn Igbo language and literature, I have watched the decline in their study in Nigeria. This experiment is designed to assess and investigate ways of teaching Igbo language and literature in order to rethink ways of improving the appreciation of Igbo studies among students. A Malian philosopher was credited with a saying that, "a dying old man is a library set ablaze". The burning library metaphor highlights the need for new ways of resuscitating Igbo culture, language and literature. It calls for exploring newer, more technologically savvy ways of preserving, presenting and promoting the appreciation of Igbo language and culture. This study seeks firsthand information on assessing the nature of teaching the Igbo language and literature, to observe how the students respond to Igbo teaching.

The teaching and studying of Igbo language and literature deserves a more scientific approach. The experiment is therefore interested in empirically initiating a new approach to the pedagogy of Igbo language and literature in a contemporary school. Its major interest is to investigate the following:

a. How Igbo language and literature is taught in secondary schools;

b. To determine how students respond to learning Igbo language and literature; and

c. Consider innovative ways of teaching Igbo language and literature in order to assess, measure and compare the students' responses to different scenarios. The outcome will help provide information towards rethinking approaches to teaching local languages and literature.

\section{Research Design and Methodology}

This qualitative study encompasses observation and semi-structured interview methods for data collection. The nature of the data collection compelled the researcher to keep notes of observation on the course of investigation, most of which helped as types of evidence, for instance, field notes on students' involuntary reactions were noted, including notes from 
informal inquiries before and after interviews with in-school students and their teachers.

\section{(a) Observation}

This study adopts observation as its major methodology. Chinguno (2015) states that observation is appropriate when the phenomenon is somehow hidden or invisible from view and exhibits important differences between the views of outsiders and insiders. Thus, observation allows the researcher to take full account of the events as they unfolded and to have a better understanding and interpretation of other findings. Deacon et al. (1999) identifies three types of observation, namely (a) Simple observation (b) Participant observation, and (c) Ethnography. Deacon et al. (1999, p. 250), define simple observation as being "a fly on the wall" where the observer has no relationship with the processes or the people being observed remain unaware of the researcher's activities. In this study, simple and participant observation were adopted.

\section{(b) Interview}

The students were interviewed in various convenient environments. Some of them were interviewed in the classroom after the experimental teaching exercise. Some were interviewed during recess period. The transcribed interviews were processed to reduce the quantity even before use. The interview was not in-depth because observation is the primary method applied in the study.

The population of this study is Class 5 students of Excellency International Secondary School, Ugwu Orji, Owerri. After checking the criteria for selecting the respondents in the study, the researcher contacted the proprietor of the school and requested to be allowed to conduct the experiment with the class which offers Igbo language and literature. Thereafter, the researcher and the class teacher had an extensive meeting designed to brief the teacher on the nature of the research. The researcher and the teacher agreed that the students will not be informed that a visitor will join the Igbo class to monitor Igbo language and literature class session. The idea is to ensure the visitor's presence does not agitate or inhibit the 
students, or cause the students to be unnecessarily nervous or conscious of the researchers' presence.

\section{Research Plan}

A typical Igbo teaching practice scenario involves a session of the teacher and the students reading through a portion of a prescribed text, and the students answering the questions or writing down the answers to the accompanying questions. The students thereafter submit the assignment to the teacher for marking. In the experimental class session, the teacher told the students that the class will involve reading through an extract from an Igbo literature text by themselves, and then answering the accompanying questions. In other words, the same method was adopted except that the text was taken from the Uremma folktale to enable the students to watch the Igbo film Odum na Akwaeke, an adaptation of the folktale. To ensure that all eighteen students participated in the experiment, the typewritten text was numbered into 18 paragraphs. The students were told they were going to have a test on the subject that was scheduled on a weekend, instead of on a weekday. The students were informed that they will read a paragraph each. Unlike in the past when they were allowed to read independently and answer the questions, they were instructed that they will read aloud because the teacher will grade them on fluency. The researcher acted as a teaching assistant to the Igbo teacher in order to watch the Igbo teacher's teaching session with her students, as an observer. The researcher helped the teacher in distributing the printed copies of the Uremma folktale. The teacher then appointed one student after another (as recorded in the class register) to read the folktale and answer the accompanying questions.

During the second part of the experiment, the researcher helped the teacher in setting up the television set and VCD player and preparing the students to watch Odum na Akwaeke. Afterwards, the students were told to write what they understood in Igbo language, how the film deviated from the folktale and which of the sections they preferred and appreciated as a means of learning Igbo language and literature. The researcher took time to keenly observe and record her findings on the course of the film viewing. 
The second session was a longer session as each part of the two-part film took approximately 90 minutes to watch.

\section{Omissions and Commissions in the two Igbo Narratives}

Although it has been stated that the audio-visual production Odum na Akwaeke is a film adaptation of the folktale, the Uremma narrative differs significantly from the Odum na Akwaeke video film production. In the folktale, Uremma married a python disguised as a human being, whereas in the film adaptation Akwaeke married a spirit disguised as a human who kept sending back the loaned body parts to various invincible owners. Those actions became signals to Akwaeke and her maidens that their lives were in danger. Secondly, in the folktale, Uremma embarked on the journey to her new home with her husband alone, but in the film adaptation, she went with royal maidens who all lost their lives before they reached their destination. Moreover, the king, Uremma's father, hired various professionals to rescue Uremma from the prison designed by the vindictive python, whereas in Odum na Akwaeke, Odum, a rejected suitor to Akwaeke volunteered to save Akwaeke from the spirit named Ogbuagu. The similarities and differences between the two narratives generated discussion and debate among the students and their teacher. They debated the relevance of the story within an Igbo cultural setting. For instance, during the question and answer sections, the teacher attempted to elicit the morals of the story from the students. While many of the students admitted that the narrative condemns pride and arrogance, the students reiterated the need to adopt the traditional mara $n g a^{2}$ practice in Igbo culture. Many of the students agreed that the absence of the mara nga made them doubt the genuineness of the story as an Igbo cultural narrative. They argued that if Uremma or Akwaeke had visited her husband's place ab initio, the whole ordeal would have been averted. Some of the controversies generated during the debates related to issues discussed previously in another study (ErnestSamuel, 2012).

\section{Research Findings based on Observation}

Owing to the teacher's claim during the reading exercise that the assessment was a class test, the students understood the exercise as a 
compulsory part of their examination. This influenced the attendance of all the students, although many seemed nervous. The tension disappeared afterwards. The following observations were made during the period of the experiment:

* During the reading session (the first part of the class), of the eighteen students in the class, eight went out before their reading turn to use the restroom. Two students dozed off and had to be woken up by their classmates. These could be indications of boredom, nervousness, and/or frustration.

* The students were not attentive. Many of them seemed to concentrate on reading ahead to ensure fluency, instead of concentrating on listening to the readers.

During the question and answer session, most of the students re-read the story independently in order to respond to the questions appropriately. This prolonged the reading session of the experiment. Consequently, the teacher elected to read through the entire story. The teacher's action positively affected the students' responses to the oral questions thereafter.

During the film preview session, however, the students were very excited regardless of the length of the film.

* None of the students went out to visit the restroom throughout the film. This could be attributed to the engaging nature of the audio-visual method, and the students' interest in the story.

The students joined in singing along to the folk songs used as a soundtrack in the film; this further enlivened the mood of the class.

There was an unexpected power outage during the film viewing. The outage was received with shouts and sighs of regrets from the students. Some of the students rose immediately to rush to the restroom, while the researcher helped the school security guard to power up the school generator. This development shows that although the students were pressed, they did not want to miss any part of the film.

The question and answer in preview session was highly interactive. Questions concerning the differences in the original folktale and the film adaptation generated an impressive debate in the class, which 
enabled the students to experiment freely with Igbo language speaking and discourse. Even the teacher was practically excited with the outcome.

When the students were told to write what they learnt from the film and the folk literature, the class became calm and in an examination mood as each student independently concentrated on writing.

* The film viewing session was like a leisure period for the teacher as she concentrated on making notes in her teaching folder.

It was observed that the teacher lacked in-depth knowledge of Igbo literature and general Igbo studies teaching, which affected her confidence before the students, and confirms the observation by Chapoo et al. (2014, p. 442) that "the success of educational reform depends on the quality of teachers". However, that shortcoming was not evident during the film viewing session. This implies that if audio-visuals are adopted as part of language pedagogy, it could support ill-trained teachers.

It was remarkable to observe that both the teacher and the students interacted casually and leisurely in Igbo language, while discussing the Igbo film, whereas, it was technically difficult for the students and their teacher to discuss the Igbo folk literature in Igbo language during the reading session. Responses during the reading were precise. This is a strong indication that film production has the potential of influencing spoken language more than a written text or literature.

The overall observation from the study indicates that there is a connection between students' increased desire to learn from audio-visual methods versus written methods. The students' reaction to the audiovisual method could be interpreted to mean that the audio-visual presentation of Igbo language and literature functions akin to oral tradition in terms of its lasting impression on the students. This furthermore suggests that oral tradition should not be considered obsolete or outdated, as it positively affects and influences the appreciation of Igbo language and literature among students. 


\section{Findings Based on Interviews}

Most of the interview extracts selected as findings provided succinct insight to the key points of this study and strengthens the contribution of this study to the discourse of language and literary study. For example, during an interview session, the teacher admitted to learning from the whole experiment.

This teaching method [has] opened my eyes to issues I never envisaged. Although reading helps develop students' reading acumen, it does not attract the desire and interest which students need to sustain interest in speaking, reading, and writing Igbo language which is significant for an Igbo studies teacher. That singular fact sets the audio-visual production ahead of the conventional teaching practiced here in Nigeria (interview extract).

This observation further exposes the usefulness and significance of this study, highlighting the connection between increased audio-visual method and the written method. The teacher admits that while individual reading by the students is important, particularly during class examinations, oral reading as done during the experimental class is more ideal and helps the students to learn how to pronounce and verbalize the language. According to her, teaching Igbo language and literature is useless if the student does not read and understand how the language is pronounced. "The audiovisual production enabled the students to hear the characters exchange conversations in Igbo language and thus help them learn to pronounce Igbo words" (interview extract). Moreover, the audio-visual production saves the teacher the stress and "headache of shouting, re-reading and going back and forth to reading" (interview extract). Importantly, the teacher admits that the film production "empowers the teacher with rich substance of issues to discuss on not only Igbo language and literature, but Igbo life and culture" (interview extract). On the other hand, it enables the students to be independent in their learning exercise and to feel more relaxed about learning. The teacher therefore saw the audio-visual production as an exciting development, because it is "a teaching aid made-easy" (interview extract).

For the students, the video production "breaks the monotony of the students sitting to listen to erroneous pronunciations" (interview extract). This submission may be assessed and compared with those studied by 
Amaechi (2013). One of the students captures the general feelings of all the students in these words:

We are used to reading the exercises on a daily basis in our Igbo classes. I guess that is part of why many of us get bored easily and even sleep in class. Reading is monotonous, particularly when the passages (narratives) do not involve folksongs or visual aids. But the film adaptation was exciting and provided us with variety which makes it more interesting. If Igbo language and literature is taught this way on a daily basis, none of us will avoid it (interview extract).

The general consensus among the students is that the film viewing method is highly educative, experimental, and requires less guidance. It also provides the teacher opportunity to observe, monitor and document notes on important areas of discourse and/or debates. By so doing, it provides the students the opportunity to discuss Igbo language and culture in Igbo language.

\section{Contradictory Aspects of Problem solving Identified in the Study}

While this pedagogical method provides the people with "useful and relevant experiences from life outside the classroom" (LSIS, 2009, p. 1), through the lenses of an audio-visual production, it is significant because it borrows from various pedagogical approaches like experiential learning, elearning, learning conversation and multi-sensory learning. However, the major problem with adopting the audio-visual viewing method is that it is time consuming. It requires utilizing more than two hours to teach a subject in one day, and will impact time for other subjects to be taught as regularly as appropriate. Most classes in secondary schools in Nigeria are allotted forty-five minutes (Okeke, 2003). A one-part video production takes a minimum of ninety minutes, meaning that a period for two subjects will be allotted to an audio-visual session. This may adversely encroach on the available time within a school calendar.

For developing countries like Nigeria, which suffers from at times unreliable power supply, such a methodology could become costly and problematic and require additional cost in providing gasoline to power generators in the school, as schools interested in adopting the method would need to have a standby power generator in case of power outage. Importantly, it means that the school management would need to furnish 
the classrooms with televisions sets and video players, and employ technicians to install and operate the equipment.

Such a pedagogical method may be controversial among proponents of decolonization like Mbembe (2015) who believe that the classroom is a site of decolonization. Yet they talk about using methods of access, which would enable Africans to see the knowledge as theirs or indigenous. Thus, as Africans open and promote conversations and debates on decolonization (also see Pietersen; Paresh, 1995), this method may be criticized for adopting 'colonial' technology and instruments as its tool of propagating and decolonizing indigenous knowledge and learning. However, the audiovisual method of teaching Igbo folktale as literature reinvents a classroom without wall which extends to the imaginations of students and their teacher, in which both the students and their teachers are co-learners, as Mbembe recommends. This makes it relevant in African classrooms.

\section{Conclusion}

This study has contributed to the discourse on the value of literary tradition in the study of Igbo language and literature. It demonstrated that the viewership of audio-visual productions has many advantages for both the teacher and the students. It supports the idea that sparking the interest of children and young people in Igbo language and literature and other local languages, requires teachers to revisit their approach to teaching such languages. Thus, in designing their workbooks, teachers need to equally think of including audio-visual aids in language studies since they have the power to increase the interest of youth in the learning of local languages and literature.

\section{Appendix}

\section{Below is the Igbo version of the Uremma folktale as published in Nza na Obu ${ }^{3,4}$}

1. Na mgbe gara ga, otu eze di onye bukwa nwoke siri ike n'ala, rue ihe eji okorobia eme. Ego wuru ya ahu, n'ihi na onye o bula kelere ya ekele, o nye ya ego hiri nne. Ma ihe na-eme ka obi ghara idi ya uto bu na o mutaghi nwa nwoke. Otu nwa naani o nwere bu Uremma bu nwanyi. Uremma bu anyanwu ututu, mba niile makwaara na o mara mma nke uku na-enweghi 
ihe eji atunyere ya. Eze di ya n'onu na enwu ka ola ocha. N'ihi ya, isi ebue ya, onaghi ahukwa mmadu; nganga eju ya obi. Nne ya bu onye gara ijisi ike dua ya odu, nwuru mgbe Uremma najubeghi ara.

2. Umu okorobia mara mma biara ka ha luo ya, ma o kwetaghi. Ma ndi bara uba, ma ndi dara ogbenye. Onye si ebe o si puta, ya abia ka o lee ma Uremma ma o ga-ekwe lua ya. Mgbe ike gwuru ha ibia, mma ya apua ha n'anya, onye joro njo ga-aka ya mma, ma o bula si na onye ahu di ka ikwighikwighi. Mgbe mma ya na ewu-ewu, umu anumanu niile makwaara na Uremma mara mma. Ufodu n'ime ha dika Agu biakwara ilu ya, ma agbogho ahu ekwetaghi. Otutu umu nwoke ndi Uremma juru ilu nwuru n'ihi obi mgbawa.

3. Anu uku ahu ana-akpo eke wee nu ihe a. o wuta ya n'obi nke mere oji kpebie n'obi ya si, "Agam aluriri Uremma, kam kuziere ya ka o ghara ikpa nganga ozo, agarakwa ime ka umu nwoke anyi nwusisia. Ya etolie ghoo mmadu, mee onwe ya ka o maa maa; gaa n'ulo eze. Mgbe o ruru n'ulo ogo ya nwoke, Uremma agbaputa, daa n'ala riowa ya ka o luo ya, kporo ya naakwughi ugwo o bula kama ime ka obi gbawaa ya. Onye no ebe o bula ono ya nu na Uremma luru di, ya akpoo mkpu. Ndi ulo eze na-anuri onu na ada eze luru di, ma asi na ha maara, ha agaghi ekwe ka eke luo nwa ha, kporokwa ya laa.

4. Mgbe ha mesiri omume di n'ilu nwaanyi, eke ejikere ikporo nwunye ya laa. O gwara ogo ya nwoke si na ya bafere uba oke, ya bu na o baghi uru ka o due ada ya ulo ebe ya nwere karia nke ga-ezuru ya na nwunye ya. Ebe eze tukwasiri ogo ya obi, o kwenyeere ya, Eke wee kporo Uremma laa. Ije ha dikwa ogologo, n'ihi na ha gafere osimiri ukwu asaa, oke ohia asaa, na ozara asaa tutu ha erue ulo eke n'akuku mmiri. N'ogologo ije ha nile, o dighi mgbe eke ahu nyere Uremma ma o bula aku ka o taa, ma ya fodu inye ya mmiri ka o nua.

5. Oge ha laruru, eke ahu asi Uremma, "Nwaanyi di mma, bia baa n'ulo mgbede gi ebe I ga-ano ma abuba". Ulo ebe o bi nwere mgbubi asaa. Nke o bula n'ime ha nwere ihe eji atuchi ya. Ha nile dikwa n'otu ahiri. Eke akporo Uremma, tinye ya na nke ikpe-azu, ya bu n'onu nke asaa, tuchichaa ha niile, loo mkpuru uzo n'afo ya ghokwaa anu, baa na mmiri ha biri. $\mathrm{O}$ kwadebere ka o mee Uremma ka o taa ahu, ka o wee nwee ike rie ya. O noo ihe di ka abali abua, o gaa lee ma o taala ahu, mgbe o ruru, o si ya, "Isikwa 
na aha gi bu Uremma? Eze nwanyim, mgbem luru gi, I joro njo, ma ugbua, o dighi ihe eji atunyere gi na mma n'elu uwa". Onye o na-agwa ihe a bu naani okpokoro isi, anya adaala a n'ekwu, ezi ka ya ocha. Odighi asa ahu, ukwu ya adighi aputa ezi. N'ezi okwu, Uremma no na mgede, ma ihe mere bu na anya mmiri gwuchara ya n'anya oge ahu.

6. Akwa Uremma na-akwa meturu nna ya n'ahu n'ihi na izu asato agafeela, ma omataghi ma nwa ya ma odi ndu ma o nwuru anwu. N'ihi ya eze achowa ndi ga eje ichota ebe ada ya no. ya agaa n'aja. Ogba aja agwa ya si na nwa ya no na-ata ahuhu na-enweghi odidi. Eze akua ekwe, kpotachaa ndi siri ike bukwa dimkpa n'ala ya, kwe ha nkwa inye ha akuku ala eze ya ma o buru na ha achota Uremma. N'ime ndia o kporo bu onye na-ezu ohi, onye oka osisi, onye ohu-uzo, onye na anya ugbo, na onye na agba egbe.

7. N'ime ndi a nile o kporo, o nwere ike iriba ama di n'omume ha nile. Onye na-ezu ohi nwere ike gaa n'ulo mmadu, onye nwe ulo ahu ga na ele ya anya ya enwerecha ihe o choro pua. O hu uzo ga ahu ihe di anya site n'ebe o bula o no. onye oka osisi nwere ike ilu ugbo na-ejighi ntu o bula; onye na -anya ugbo, ga enwe ike nyaa na-ejighi amara-ugbo; onye naagbakwa egbe nwekwara ike gbagbue onye iro ya ma o jighi mgbo. Umu nwoke ndi a gara ichota Uremma n'ihi na ihe ha juru eze afo. Ha gara ije izu abua rue be eke n'ihi na ha mere ka ha gaa ngwa ngwa tupu eke erie ada eze ha riri mma.

8. Mgbe ha ruru, eke no n'akuku mmiri na-ezuru ike, na-ele ha anya. Mgbe ugbo ha kwusiri, onye ohi aputa ilu olu ya, o meghepu onu eke, tinye aka n'afo ya, weputa mkporo uzo, ga meghee ulo ya niile, kpoputa ada eze. Anya ha huru Uremma gbaputara ha anya mmiri, o rikwara ha onu. Ma oge adighi maka iju ajuju. Onye ohi ahu ewere kwa mkporo uzo ahu tinye kwa eke n'onu ya kporokwa nwa ahu, onye obula gosiri ihe obula o mutara. Mgbe ha jere ije otu ubochi, eke ahu abia mata iwi wiri ya na ihe ojoo mere ya, na mmadu biara n'anya ocha bia nara ya nri dabatara ya n'onu. Ebe o toro ogologo, igwu mmiri araghikwa ya ahu, ochusobe ndi iro ya, ndi biara icho onwu ya.

9. Onye ohu uzo, mgbe eke ahu no na nkume uzo isii, o gwa ndi ha na ya so, si na eke bulitere isi ya n'elu mmiri wee hu ebe ha no. mgbe eke ahu biaruru ugbo ha, o were odu ya piwaa ugbo ahu. Otu oge ahu onye egbe 
agbaa tuwii na-ejighi mgbo, onye oka osisi akua "dai, dai, dia" na ejighi ntu, onye na-anya ugbo egosi na o ma olu ya n'ezie.

10. Otua ka ha na eke lugidere ogu rue mgbe ha gafechara oke osimiri asaa ahu di n'uzo. O rue mgbe ha bara n'oke ohia na eke ahu ghoro odum na emenye ha ujo n'ahu.

Ndi olu ha kasi mkpa n'oge ahu bu onye egbe na onye ohu-uzo. N'ozara kwa, eke ahu ghooro ntakiri anu mere ogwu ogwu na-akpagbu Uremma, n'emepu ya obara n'ahu. Ma ha jiri ike, bu umu nwoke n'etiti ndu n'onwu, kpolatara eze ha ada ya.

11. Mgbe ha ruru ulo, eze wee kpoo oriri, na agba egbe, I baa n'obi eze, o buru anuri. Ha kutere efere mmiri asaa buru ibu, otu ogoro ncha na ogbo buru ibu wee saa Uremma ahu site n'ututu rue n'anyasi ka elee ma oga-adi ocha di ka o di na mbu.

12. N'ikpe-azu, oge emechara emume ahu, ndi gara kpolata Uremma biara n'ulo eze ka o mezue nkwa o kwere ha. Eze nyere ha otu uzo n'ime uzo ato ala eze ya na n'ihe nile o nwere. Esemokwu wee putara ha, n'ihi na onye o bula n'ime ha chere na olu nke o luru kasi mkpa.

13. Ha wee kpo ikpe ubochi a ga-abia ka ekee ihe eze nyere ha. Mgbe ha nile zuru, onye ohi ebilie si, "Umunna $\mathrm{m}$, unu ma na ihe a kporo izu ohi abughi ntakiri olu. O bu olu choro dimkpa. Leenu, agaram, weputa mkpuru uzo meghee uzo, kpoputa Uremma. O buru na ejisighim ike zute mkporo uzo n'afo eke, olee uzo unu gara isi kpota ada eze?

14. Echere $\mathrm{m}$ si na emeela $\mathrm{m}$ ka okorobia, ya bu n'oke nkem, kasi nke ndi ozo." Onye ohu uzo ataa ikiriki eze, bilie si, "Ndi amala, ndewonu. Anurum ihe nwannem bu onye ohi kwuru. O bu eziokwu na o mere ihe siri ike, ma asi na anyi na-alata, ahughi $\mathrm{m}$ eke ahu, ghara ikara ha ka ha jikere, echerem na anyi gara ino n'ime mmiri ugbua. Nke a gosiri na m zoputara ndu ha mile.

15. Ogba egbe asi, "Ndi nile na-achu nta n'ime umu mara otu o si ara ahu igba egbe ma ewere mgbo. Umunnem, unu ahula onye ola di mbu agba egbe na ejighi mgbo? Ya bu unu kwusia nke unu, o buru na unu ekpetaghi onum, agahim ekwe!"

16. Onye oka osisi, odighi ya nke ibili oto, onodu ebe o no si, "Unu umuntakirim, obughi agadi di kam ga-anodu bia itufu oge. Onye o bula 
ahula nam mere ka unu ghara inwu na mmiri mgbe eke jiri odu ya piwa ugbo. Ya mere, obughi oke ihe ma unu si m kam werechaa ihe nile eze nyere anyi." Onye na-anya ugbo asi, "N'eziokwu nile, ahurum ntim anya n'inya ugbo. Lee otu aka $\mathrm{m}$ di mmiri eribesiela ya. $\mathrm{O}$ buru na unu enyem ihe nochiri mkpisi aka irim, o zuerelam."

17. Ndi eze ikpe amaghi onye ha ga enye ihe nke ka. Eze aputa, tulee ihe nile ha mere; ka e wee kwusi esemokwu, owere aka ya kee ihe nile ahu uzo ise, umu nwoke ahu ewere obi ocha nara oke o bula nke o nyere ha. Emesia, onye gbara eze aja aputa si, "O kechara oke fodu bu iro. Eze nyekwam oke ruru $m$, n'ihi na emerem gi ihe oma." Eze kwe n'isi si na obu eziokwu, nyetukwa ya ihe nke ruru ya.

18. Site n'ubochi ahu Uremma akpaghi nganga ozo. Emesia o lua di, muta umu abua, kpo otu Ngangaebeela, nke ozo bu Iheonunekwu. Uremma hukwa onye na-akpa nganga, o si ya, "Nwa nnem, biko, kwusi nganga ihe mere Uremma emee gi." Chakpii! Woo! O gwuchaala.

\section{English Translation OfUremma Folktale}

1. In the past, there was a very strong and reputable king. He was so wealthy; that he gives money generously to anyone who greets him. The only thing that makes him sad is that he has no son. His only child is a girl named Uremma. Uremma is very beautiful that she was incomparable in the land. She has the most sparkling set of teeth. Consequently, she was so proud and arrogant. Her mother who would have been a good influence and adviser had died when Uremma was still breast feeding.

2. She turned down all the handsome suitors who wanted to marry her. Even the rich and poor. People from all walks of life came to propose to her, but she refused them all. When they got tired of coming, they ignored her beauty. The ugly ones, even those that look like owl seemed better. While her beauty reigned, even animals knew that Uremma was smashingly beautiful. Some of them like a Lion even came to marry her but she turned it down. Many of the suitors she turned down died of heartbreak.

3. A great animal called the python heard about this. It pained him so much, that he concluded, "I must marry Uremma, so that I will teach her not to be arrogant again, or to cause our young men to die". It turned into 
a dashing human being, and went to the Eze's palace. When he arrived the Eze's palace, Uremma came out and fell on the ground and appealed to him to marry her without paying her dowry, instead of allowing her to die of heartbreak. When people heard that Uremma got married, they shuddered. The royal family were happy that the Princess finally got married, but had they known, they would not have allowed a python to marry the Princess and take her home.

4. When the marriage rites had been concluded, the python got ready to take his wife home. He told his in-law that he is very wealthy, therefore, he does not need anything from him as he has enough for them. The King trusted his in-law so he agreed. The python then took Uremma home. It was a very long journey, as they crossed seven rivers, seven forests and seven deserts. Throughout that long journey, neither did the python give Uremma any nut to chew, nor water to drink.

5. When they got home, the python said to Uremma, "Beautiful woman, enter your bridal fattening room, where you will be fattened". The house has seven outlets and each of them has a key. All of them are in a lateral line. The python kept Uremma in the seventh and last one and locked up the entrance. It swallowed the key and then entered the river to live therein. Its plan is to make Uremma slim down so that it can swallow her. After every two days, it goes and examines her. When it gets there, it tells her, "Did you say your name is Uremma? My Queen, when I married you are ugly, but now, you're incomparable to none all over the world". Meanwhile, the person it was talking to was only a skeleton, with hollow eyes and as dirty as a pig. She does not bath and neither does she go out. Uremma was in deep regret and pain, but she could not cry as tears have already tried from her eyes at this point.

6. Uremma's sorrow affected her father who had a premonition given that it has been more than eight weeks he has not heard from her, and so does not know if she was dead or alive. Consequently, the King began to seek for someone to search for his daughter. He went to a seer. The seer informed him that his daughter was in great indescribable sorrow. The King summoned all manners of men in the land with a town crier and promised to divide and share part of his kingdom, if they will rescue Uremma. 
Among the men selected for the adventure were a thief, a carver, a surveyor, a driver and a marksman.

7. Each of these men has a remarkable talent in what he does. The thief can stealthily sneak into someone's house; the owner may be looking at him as he steals and leaves. The surveyor can see clearly from any distance. The carver can carve a new boat with ease without the aid of nails. The driver can paddle the boat without paddles. The marksman can kill an enemy without a bullet. These men set out to search for Uremma because the King has confidence in them. It took them two weeks to get to the python's house because they were in a haste to get to Uremma before the python swallows her.

8. When they arrived, the python was resting close to the river bank and looking at them. When their boat stopped, the thief came down to practice his art. He opened the python's mouth and inserted his hand into his mouth down to his stomach to collect the key of the doors. He opened all the doors and brought out the Princess. They were close to tears when they saw Uremma. They were speechless. There was no time for questions. The thief put back the key in the python's mouth and took the girl away. All the men exhibited their arts. When they had traveled for one whole day, the python began to realize his unfortunate loss. With its length, swimming was not a problem to it. It began to run after its enemies who wanted it dead.

9. When the python was six oceans away, the surveyor saw the python's head as it swims towards them, he alerted his colleagues. When the python got so close, it broke the boat with a dash of its tail on the boat. Instantly, the marksman shot at it without a bullet. The carver repairs it with "dai, dai, dia" without any nails. The boat-driver paddles with expertise to show excellence in his occupation.

10. They kept faith in this way until they past the seven seas. When they entered the huge forest, the python changed into a tiger to frighten them. The persons with the most significant assignments are the marksman and the surveyor. In the desert, the python became a small porcupine with thorns and pierces Uremma's body, causing her to bleed. However, the men did their best to ensure they bring the Princess back to her father. 
11. When they arrived home, the King organized a feast. The palace was filled with rich celebration and cannons were shot in celebration. The King was overjoyed. They fetched seven big basins of water, one long bar soap and sponge to bath Uremma from morning till night, in order to see if it is possible to get her as glowing as she used to be.

12. Finally, when he concluded the celebration, the men who went on the mission came to the King that he may fulfill his promise. The King gave them one-third of his kingdom. There was a disagreement as each felt his assignment was more important than the other.

13. They called judges to partake in the sharing of the rewards. When they gathered, the thief stood and said, "My kinsmen, you know that stealing is not an easy task. It is a task that demands bravery. See, I went and stole the key and brought out Uremma. If I did not steal out the key which was swallowed by the python, how would we have brought out the Princess?

14. I think I acted as a brave man, meaning that my share should be larger than everyone's share". The surveyor gnashed his teeth, rose and said, "Elders of our land, I heard what my brother the thief said. It is true that he did a great job, but if as we were returning, I did not survey and see the python and told others, I believe we would have been in that sea by now. This shows that I saved all of us".

15. The marksman said, "The hunters among you know how difficult it is to shoot a gun with a bullet. My kinsmen, have you seen anyone who shoots without a bullet? Therefore, if after your commentaries, your decision did not favour me, I will not agree!"

16. The carver did not feel like standing up to speak. Sitting on his seat, he said, "You children, an elder like me will not waste time. Everyone saw that I made it possible for you not to drown in the sea when the python broke the boat with its tail. Therefore, it is no big deal if you all agree to let me take everything that the King gave us." The boat-driver said, "Truly, I saw hell in paddling the boat. See how my palms are. The water has left its toll on them. If I am given what adequately replaces my ten fingers, it is enough for me".

17. The judges did not know who to give a preferential share. The King came and examined the case and personally divided the share into five 
portions. The men took the shares he allotted them in good faith. Later, the seer came and said, "He who divided and left out some did so in bad faith. Our King, give me my own share because I did you a good favour". The King nods and agreed he spoke the truth and gave him his own share.

18. From that day onwards, Uremma did not exhibit pride again. Afterwards, she got married and had two children. She called one Ngangaebeela (Pride has ended), the second one is Iheonunekwu (What the mouth says). When Uremma sees a proud and arrogant fellow, she says, "My child, please control your pride so you don't meet with Uremma's fate". Chakpii! Woo! The end.

\section{Notes}

1 Available at: <https://edtechnow.tech/2013/05/12/pedagogy/>.

2 Mara nga literally means "know the place" in Igbo language. It is a cultural practice which allows a bride to pay a brief visit to the place she is about to be married into before the marriage ceremony, in order to know, understand and assess if she would want to live permanently in that environment.

3 The folktale has been published in many other Igbo literature anthologies too numerous to be mentioned.

4 The English translation is attached as appendix after the references. The video film, Odum na Akwaeke can be accessed through this link: $<$ https://files.ng/view/movie/odum-na-akwaeke-1-2>.

\section{References}

AMAECHI, Jerome. Students' Perspectives on English-Only Instruction: A Study of Three Junior Secondary Schools in Eastern Nigeria. Michigan: Proquest Dissertation Publishing, 2013.

ASONYE, Emmanuel. UNESCO prediction of the Igbo language death: Facts and Fable. Journal of the Linguistic Association of Nigeria, Nigeria, v. 16, n. 1-2, p. 91-98, 2013.

CHAPOO, Suriya et al. Biology Teacher's Pedagogical Content Knowledge in Thailand: Understanding \& Practise. Procedia - Social and Behavioral Sciences, Elsevier, v. 116, p. 442-447, 2014. 
DEACON, David et al. Researching Communication: A Practical Guide to Methods in Media and Cultural Analysis. New York: Oxford University Press, 1999.

ERNEST-SAMUEL, Gloria. E-Culture and African Video Films in a Globalized World. UJAH: Unizik Journal of Arts and Humanities, v. 13, n. 2, p. 53-70, 2012. Available at: <http://dx.doi.org/10.4314/ujah-v13i2.3>. Accessed on: 7th April, 2018.

ILOENE, Modesta et al. The Use of New Technologies for the Teaching of the Igbo Language in Schools: Challenges and Prospects. Voldans: La Granges des Noyes, 2013.

LSIS. Learning \& Skill Improvement Service. Ten Pedagogy Approaches Equality and Diversity Quick Start Guide. 2009.

MBAH, Evelyn et al. Podcasts for Learning English Pronunciation in Igboland: Students' Experiences and Expectations. In: BRADLEY, Linda; THOUESNY, Sylvie (Ed.). 20 Years of EUROCALL: Learning from the Past, Looking to the Future. Research Publishing.net. 2013.

MBEMBE, Achilles. Decolonizing Knowledge and the Question of the Archive. 2015.

ODINYE, Isreal; ODINYE, Ify. Preventing the Extinction of Igbo Language. OGIRISI: a New Journal of African Studies: Editorial Policies, Nigeria, v. 7, p. 85-93, 2010.

OKEKE, Matthew O. Nigerian Educational Curriculum: issues and prospects. Owerri: Roban Publishers, 2003.

PIETERSEN, Jan Nederveen; PARESH, Bhikhu. The Decolonization of Imagination: culture, knowledge and power. London: Zed Books, 1995.

UBIOWORO, Eyo; ONOYOVWI, Doe. Towards re-tooling oral literature for the teaching of Nigerian Languages. Journal of Nigerian Languages and Culture, Nigeria, v. 10, n. 2, p. 135-146, 2008.

WILLAM, Dylan. Five Principles of Pedagogy. Ed Tech Now. 2013. Available at: <https://edtechnow.tech/2013/05/12/pedagogy/>. Accessed on: $7^{\text {th }}$ April, 2018. 
Gloria Chimeziem Ernest-Samuel a lecturer in Theatre Arts department, is an academic board member of the Faculty of Humanities, Imo State University, Owerri, Nigeira. She holds a Doctor of Philosophy in Media Studies from the University of the Witwatersrand, Johannesburg. Her research interest spans across African films (Nollywood), cultural, communication and literary studies. She is widely published in many literary and academic journals.

ORCID: http://orcid.org/0000-0001-5066-8998

E-mail: gloimsu@yahoo.com

This unpublished text, proofread by Ananyr Porto Fajardo, is also published in Portuguese in this issue.

Received on 16 April 2018 Accepted on 17 September 2018

This is an open-access article distributed under the terms of the Creative Commons Attribution License 4.0 International. Available at: <http://creative commons.org/licenses/by/4.0>. 